\title{
STRUCTURAL AND LEGAL ANALYSIS OF BANKING SAFETY IN UKRAINE
}

\author{
Olena Dzhafarova ${ }^{1}$, Olena Riabchenko ${ }^{2}$, Igor Artemenko ${ }^{3}$
}

\begin{abstract}
The article is devoted to the scientific analysis of Ukraine's economic activity under the conditions of European integration processes. It is stressed that the value of the current economic activity is primarily determined by the processes of globalization, the formation of market relations, need for creation of guarantees in these conditions that will ensure a decent life for all members of society because of the need for ensuring the economic and overall national security of Ukraine. However, it is necessary to consider that the access to world markets and formation of an open economy also mean an internal stability of the economy and financial system of the state. The purpose of the article is to clarify the concept of banking security, its main components and levels of development. The report data of the Deposit Guarantee Fund (DGF) and the Prosecutor General's Office of Ukraine for the last years have been analysed. It also testifies about the lack of control and superficial attitude of the controlling bodies towards the processes of the banking sphere criminalization. It is determined that the DGF indicators do not correspond to those of the Prosecutor General's Office of Ukraine reports regarding the crimes committed in the sphere of banking. The government of Ukraine should focus on domestic reforms, the creation of living standards, economics and politics in Ukraine, which are as close as possible to European. Only then it is possible to implement effective mechanisms aimed at neutralizing, minimizing the impact and eliminating the phenomena and factors leading to the creation of external and internal threats to the state's financial security.
\end{abstract}

Key words: banking activity, banking security, state, economy, economic activities, world-economy, economic legislation, economic transformation, integration, globalization.

JEL Classification: D63, G21

\section{Introduction}

Ukraine has made a European choice as the main direction of its state policy, both internal and external, whose ultimate goal should be the full membership in the European Union. For Ukraine, European integration, on the one hand, this is the way of modernization of the economy, attracting foreign investment and technologies, increasing the competitiveness of domestic manufacturers, access to world markets, including the market for financial services. On the other hand, access to world markets, the formation of an open economy also means that the economy and financial system of the state must be internally stable, able to withstand the risks that accompany the processes of globalization and European integration.

The processes of integration of the Ukrainian banking sector into Europe provide for the taking concrete measures aimed at ensuring the stability and enhancing the banking sector competitiveness.
Crime in the banking sphere was the focus of many researches in Ukraine; however, they do not have a comprehensive scientific analysis of banking criminal legal protection. To solve the criminalization problem in banking, as well as to protect customers' rights and improve their financial health taking into account the interests of creditors, the appropriate mechanisms are introduced. And this, in turn, requires regulatory and legislative framework improvement. Effective functioning of the Ukrainian banking system, as well as individual banking institutions, requires the conditions under which the impact of external and internal adverse factors will not result in negative effects. They can be provoked by any transformations that arise under the instability against reforming the banking system and military events in eastern Ukraine.

Particularly relevant in the context of strengthening the European integration processes of Ukraine is the determining the legal framework for ensuring bank

\footnotetext{
Corresponding author:

${ }^{1}$ Kharkiv National University of Internal Affairs, Ukraine.

E-mail: olenadzhafarova@gmail.com

${ }^{2}$ University of the State Fiscal Service of Ukraine, Ukraine.

E-mail: 80677171865@ukr.net

${ }^{3}$ Court of Appeal of the Odesa Region, Ukraine.

E-mail: IA_2018@ukr.net
} 
security, which must comply with the international standards established. Strengthening the country's banking security and adapting domestic legislation to the provisions of the Directives of the European Parliament and of the Council are complicated by significant criminalization of the Ukrainian banking sector.

Modern EU regulatory requirements and mechanisms aimed at reducing credit risks and ensuring the financial sector stability in foreign countries can be ratified and properly implemented in domestic legislation, in particular, in the Ukrainian banking sector, only if the level of shadow economy of Ukraine and the criminalization of economic processes are reduced, in particular in banking.

The European integration intentions of Ukraine have made changes to the development of its economy and, in particular, to the financial sphere. Substantially, these changes affected the banking system development, which is a systemic element of the financial and credit market. The essence of these changes manifests itself in the increase of foreign banks presence, the need to implement the EU banking legislation norms and methods of banking business in the domestic practice. All this determines the urgency of the effective development of economic and legal aspects of Ukraine's banking security in the European integration context. In the economic system of Ukraine, banks often play a crucial role, and hence the issue of banking security has been widely covered in the economic literature. Baranovskyi (2014) reveals that such a decisive role of banks is primarily due to the simultaneous functionality of a bank as a monetary institution, financial intermediary, and securities market intermediary.

M. Kurylo, A. Klochko, D. Zhuravlov, H. Javadov (2018) reveal that permanent or sudden negative effects that arise in any field of activity may affect the final result of the bank's activities. They may be of different origin and can cause damage both to the banking institution itself and to all entities with which it is associated. Therefore, it is necessary to ensure conditions, under which the action of external and internal factors will not lead to negative processes.

Such conditions form a complex concept of banking security, which leads to a significant number of approaches to its definition. Vasylchak (2009) finds out that the security of a bank is a state of sustainable life, which ensures the implementation of the main interests and priorities of the bank, and protection from external and internal destabilizing factors. Prokopenko (2014) considers banking security as a qualitative attribute and characterizes it as a state, in which there are no dangers.

Vovchenko (2015) appeals to the complex and multidimensional notion of banking security. He interprets it as a certain state; possibility of further development; function of the state; regulation of the obligatory economic standards and requirements; the activities of the central banks, state bodies, as well as commercial banks for management functions while conducting banking transactions and making the deals; a set of technical regulations and requirements.

According to Deloitte International Company, 93\% of respondents claim the level of fraud in the banking sector has increased significantly over the past two years. Considering significant losses, banking institutions should develop appropriate measures to improve banks' reputation (Jayaprakash, 2016). A similar issue is the focus of the international study by Migiro (2016), who studies the optimizing the bank's loan portfolio and credit rating as the ways to improve bank efficiency and financial stabilization of the banking system. In their study, Swanepoel and Smit (2016) have proven that the banking industry sustainability plays a significant role in overall economic development. Shcherbatykh (2016) links the security of a single bank with the security of the banking system as a whole. In his opinion, they affect one another. Problems that arose in one bank can cause a "domino effect" and lead to a systemic banking crisis.

According to Weigand (2016), "U.S. banks continue to exhibit a more robust post-crisis recovery, while Japanese and European banks continue to experience crisis-level conditions." Similar dynamics are also observed in the banking segment of the United Kingdom since the total amount of fraud loss in 2016 amounted to 200.1 billion pounds sterling. Fraud losses are distributed according to the type of services provided: payment cards, checks or remote services. In the UK, for example, about $80 \%$ of fraud occurs with payment cards, $18 \%$ - in the remote customer support, and only $2 \%$ of violations are related to checking transactions (Steele, 2017). Konig (2017) notes that recent financial crises have highlighted the need to create an effective structure for large EU banks at the international level in order to enhance financial stability. Improving the banking system stability, for example, assessing credit risk and improving bank decision-making processes are discussed by Al- Shawabkeh and Kanungo (2017). Weigand researched efficiency, growth, combination of assets, risk, operational efficiency, profitability, and capital reserves of the 20 largest banks in Japan, the United States, and Europe for 2003-2015 and made a conclusion that all banks hold more capital of the first level, than it is provided by the Basel III agreement, which led to a deep decrease in their net profit and returns on equity. Nowadays, Ukraine needs solving the issue that arose in the new political and economic conditions (Klochko et al., 2017). Moreover, the active course of Ukraine at European integration involves bringing banking legislation in line with the EU requirements (in particular, with regard to the implementation of the provisions of the Basel Committee on Banking Supervision directives). As a part of the implementation of the EU-Ukraine Association Agreement and the Comprehensive Program for the Development of the Financial Sector of Ukraine by 2020, the NBU continues 
to implement the EU directives in the Ukrainian banking activities. However, these processes are accompanied both by positive and negative shifts, in particular, by raising the level of social relations criminalization in the banking sector. This is to some extent due to the fact that the domestic banking system is not yet sufficiently adapted to the crisis in the economy and the dynamic changes in legislation, as well as to the spread of various abuses and corruption in this area. Therefore, any changes are stressful and are accompanied, as a rule, by unpredictable processes, which lead to socially dangerous consequences. The purpose of the article is to analyse the legal principles of banking security and its correlation with the criminological security of banking institutions in the context of European integration of Ukraine. The authors' research focuses on developing economic and legal measures directed at strengthening the country's banking security.

As another example, the Fund for the Guaranteeing of Individuals' Deposits (2016) has recently filed 234 applications against the owners and managers of insolventbankstotalling 88.7 billionUAH, of which claims for making the bank insolvent amount to 36.9 billion UAH. In total, the Fund filed 1,291 applications for crimes totalling 115.9 billion UAH. Khvorostina and Yanitskiy (2017) reveal that according to the Fund's executives, more than 117939 enforcement proceedings on their claims are executed in the State Enforcement Service bodies as of February 23, 2017. But it is very difficult to find examples of criminal cases initiated, and even more so with regard to cases brought to trial. The purpose of the article is due to the fact that banks in the economic system of Ukraine play a decisive role. In previous studies, authors have repeatedly emphasized that the Ukrainian banking is a valuable object of criminal law protection (Klochko \& Nezhevelo, 2017), which requires legislative changes aimed at the formulation of appropriate security provisions.

The article explores the concepts of banking security, criminological security of banking institutions, their content, relationships, and values for accelerating the bringing of Ukraine's legislation in line with the international law, in particular with the provisions of the EU Directives on Banking Supervision. The methodological basis of the article is a set of methods and techniques of scientific cognition.

As a general scientific method, a systematic approach is used, which allowed us to determine the problematic issues of adaptation of the Ukrainian legislation to the international legislation provisions. The use of this method determined the study of internal causation, structural-functional, hierarchical, direct, and inverse relations, which allowed identifying the complex processes of banking development in Ukraine, the nature of certain economic processes and phenomena.

The documentary analysis made it possible to develop proposals and recommendations for further development of the criminal statistics in order to find out the actual state of criminalization of the banking activity in Ukraine. Transformation processes in Ukrainian banking sector demonstrated that the National Bank of Ukraine (hereinafter - NBU) does not perform sufficient functions to ensure the hryvnia's stability (three significant devaluations: 1998-1999, 2008-2009, and 2014-2017), and also to hold price stability. There are instability and widespread bankruptcy of banks. Special attention should be paid to some discrepancy, namely: the share of crime in the economic, financial, banking, and budgetary spheres has not exceeded 3\% in recent years. The comparison method allowed to compare the existing categories of banking security and the criminological security of banking institutions and to conclude that the existing economic and legal categories are, to a certain extent, interrelated and interdependent. This is due to the fact that their content reflects in general the state of its security of banking institutions from external and internal destabilizing factors. The authors also addressed the relevant legal journalism, on pages of which separate questions are being discussed concerning the issues of the research. Methods of legal statistics were used to determine the quantitative indicators of certain types of criminal offences in banking.

The study objective is to analyse the current Ukrainian legislation (the Criminal Code of Ukraine) aimed at preventing violations of banking legislation and making suggestions for their improvement.

\section{Criminal offenses in banking or the 2013-2018 period according to annual reports' data of the Prosecutor General's Office of Ukraine}

Reported data of the Prosecutor General's Office of Ukraine also contain contradictory and ambiguous criteria for determining the indicators of committing crimes in the banking sector. In particular, in the annual reports of the Prosecutor General's Office of Ukraine from 2011 to 2017, there are concepts that indirectly characterize the number of criminal offenses committed in the banking sector. In particular, we are talking about the following categories: crimes in the sphere of economic relations on credit and financial activity; crimes in the banking system; crimes in the field of economic activity; crimes in financial and insurance activities; crimes in the field of monetary intermediation; crimes related to the central bank activities; crimes in other types of monetary intermediation; crimes in other types of lending; crimes with regard to other financial services except for insurance and pension provision.

Thus, according to the report on the Prosecutor's work for 12 months of 2013, 527 criminal cases were filed in the field of economic relations on credit and financial activity; in the banking system - 260 . 
According to the report of the Prosecutor's work for 11 months of 2014,141 criminal proceedings were instituted in the field of economic relations on credit and financial activity; in the banking system -89 .

During 12 months of 2015, according to the report on the Prosecutor's work, 175 criminal proceedings in the sphere of economic relations on credit and financial activity were instituted. Note that in the 2013 report, there is no criterion of crimes committed in the banking system, as indicated in the previous reports on the Prosecutor's work for 2013-2014.

According to the unified report on criminal offenses for 2013, taking into account the classification of offenses in banking specified above, we have registered: under Article 200 of the Criminal Code of Ukraine - 260 criminal offenses; under Art. 222 of the Criminal Code of Ukraine - 327; under Art. 231 of the Criminal Code of Ukraine - 17; and under Art. 222 of the Criminal Code of Ukraine - 12 criminal offenses were registered.

According to the report on the Prosecutor's work for 12 months of 2014, 7 criminal proceedings were initiated in the area of economic activity to prevent and counteract the legalization of proceeds from crime, 1 of which was sent to the court. It should be noted that in the 2014 report, there is no criterion such as "credit and financial activity", which is indicated in the previous reports for 2011-2012. According to the unified 2014 report on criminal offences, the following is recorded: according to Art. 200 of the Criminal Code of Ukraine - 285 criminal offenses; under Art. 222 of the Criminal Code of Ukraine - 345; under Art. 231 of the Criminal Code of Ukraine - 26; and under Art. 232 of the Criminal Code of Ukraine - 8 criminal offenses.

In the report on the Prosecutor's work for the 12 months of 2015, the quantitative criteria by the activity areas have disappeared. Thus, according to the unified report on the criminal offenses for 2015, it is recorded: under Art. 200 of the Criminal Code of Ukraine - 238; under Art. 222 of the Criminal Code of Ukraine - 129; under Art. 231 - 14; and under Art. 222 of the Criminal Code of Ukraine - 5 criminal offenses.

According to the unified report data on the criminal offenses for 2016, the following is recorded: under Art. 200 of the Criminal Code of Ukraine - 167 criminal offenses; under Art. 2181 of the Criminal Code of Ukraine - 6; under Art. 2201 of the Criminal Code of Ukraine - 1; under Art. 2202 of the Criminal Code of Ukraine - 1; under Art. 222 of the Criminal Code of
Ukraine - 62; under Art. 231 of the Criminal Code of Ukraine - 19; and under Art. 232 of the Criminal Code of Ukraine 7 criminal offenses were recorded.

The data of the report on the criminal offenses committed at the enterprises, in institutions and organizations by type of economic activity in 2015 show: with regard to financial and insurance activities there were 4,983 registered criminal offenses, out of which 1,104 were in the field of monetary intermediation (among which with regard to the central bank's activity 462 criminal offenses were registered, other types of monetary intermediation - 642). In the sphere of financial leasing, 76 criminal offenses were registered; other types oflending - 1,112; in the field of providing other financial services except for insurance and pensions 3,420 criminal offenses were registered.

In 2017, according to a unified report on the criminal offenses, pre-trial investigations for which were carried out by the National Police, the following was recorded: under Art. 200 of the Criminal Code of Ukraine, 383 criminal offenses were registered; under Art. 2181 of the Criminal Code of Ukraine - 4; under Art. 2201 of the Criminal Code of Ukraine - 0; and under Art. 2202 of the Criminal Code of Ukraine - 1 criminal offense (Ter-Akopov, 2003). Specified information on criminal offenses in banking for the period of 2011-2016 according to data of annual reports of the Prosecutor General's Office of Ukraine is presented in Table 1.

Taking into account the classification of offenses in banking proposed by the authors, their dynamics are seen in accordance with the available data of the Prosecutor General's Office of Ukraine (Table 3).

The problem is the lack of the courts' practice of using criminal liability legislation for offenses committed in the banking sector. Directly related to these categories of criminal offenses is the Resolution of the Plenum of the Supreme Court of Ukraine No. 3 dated April 25, 2003: "On the Practice of Using by the Courts the Legislation Regarding Liability for Certain Crimes in the Economic Activity”. The provisions of the Resolution of the Plenum of the Supreme Court of Ukraine No. 5 dated April 15, 2005, are also useful in considering certain types of crimes in banking: "On the practice of applying by courts the regulations of criminal liability for legalization (laundering) of proceeds from crime". However, the lack of a concretized practice in criminal cases concerning offenses committed in the banking sector complicates their effective judicial review and fair decisions adoption.

\begin{tabular}{|c|c|c|c|c|c|c|c|c|c|}
\hline Year & $\begin{array}{c}\text { Art. 200 } \\
\text { of the CC } \\
\text { of Ukraine }\end{array}$ & $\begin{array}{c}\text { Art. 209 } \\
\text { of the CC } \\
\text { of Ukraine }\end{array}$ & $\begin{array}{c}\text { Art. 218 } \\
\text { of the CC } \\
\text { of Ukraine }\end{array}$ & $\begin{array}{c}\text { Art. 219 } \\
\text { of the CC } \\
\text { of Ukraine }\end{array}$ & $\begin{array}{c}\text { Art. 220 } \\
\text { of the CC } \\
\text { of Ukraine }\end{array}$ & $\begin{array}{c}\text { Art. 220 } \\
\text { of the CC } \\
\text { of Ukraine }\end{array}$ & $\begin{array}{c}\text { Art. 222 } \\
\text { of the CC } \\
\text { of Ukraine }\end{array}$ & $\begin{array}{c}\text { Art. 231 } \\
\text { of the CC } \\
\text { of Ukraine }\end{array}$ & $\begin{array}{c}\text { Art. 232 } \\
\text { of the CC } \\
\text { of Ukraine }\end{array}$ \\
\hline 2015 & 238 & 58 & - & - & - & - & 129 & 14 & 5 \\
\hline 2016 & 167 & 140 & 6 & - & 1 & 1 & 62 & 19 & 7 \\
\hline 2017 & 383 & 160 & 7 & - & 3 & 2 & 67 & 24 & 17 \\
\hline 2018 & 392 & n/a & 6 & - & 1 & 1 & 55 & 36 & 17 \\
\hline
\end{tabular}




\section{Economic and legal aspects of banking security under European integration intensification in Ukraine}

The National Bank of Ukraine (hereinafter - the NBU) is carrying out work on the implementation of the four fundamental acts for the banking sector: EU Directive 2013/36 and EU Regulation No. 575/2013 (the so-called CRD/CRR IV package), which establishes the rules for access to credit institutions' activities, defines supervisory powers and instruments of prudential supervision; Directive 2002/87/EU on supplementary supervision of banking groups; Directive 2009/110/EU, which defines the rules for the establishment, implementation and prudential supervision of the activities of institutions working with electronic money. In addition, the NBU continues to adapt its own regulatory framework, taking into account the recommendation of the FATF AntiMoney Laundering Group and the provisions of the EU acts, in particular, Directive 2015/849/EU and Regulation 2015/847/EU.

They relate to enhancing the efficiency of prevention and counteraction to money laundering and terrorism financing. Banks often don't share much about their security techniques since they don't want to tip off criminals on how best to attack them. Whether they talk about it or not, financial firms should be encrypting data, segregating credit card information from other types of data, and making web applications as secure as possible (Palmer, 2011).

The superficial attitude of banking institutions to their own security leads in some cases to negative consequences, the most unfavourable of which are criminal offenses. In the context of the banking activity criminalization in Ukraine, the adaptation of domestic legislation to the EU requirements must be secured appropriately at the criminal law level. The criminological security of a banking institution is defined as its protection against criminal threats by means of factors that will enable them to anticipate, avoid or counteract them, taking into account certain environmental conditions specially created. As practice shows, banking institutions suffer the greatest losses from criminal offenses, which in criminological terms can be divided into the following groups: mercenary and violent crimes; financial and economic crimes; computer thefts.

Consequently, criminal threats to the banking institutions security by their sources are divided into two different types in terms of the nature and degree of danger: external - the output of certain factors of the banking institutions environment; and internal the output of the banking system itself. Criminological security in this aspect is defined as a state of protection of banking institutions, property and individuals from external and internal threats by criminal law (Ter-Akopov, 2003).
In the current Criminal Code of Ukraine (hereinafter the CC of Ukraine) among the criminal law prohibitions imposed by the legislator, which establish liability for illegal acts in banking, we distinguish a group of criminal law standards in accordance with their specific object. This group includes the following crimes: illegal actions with transfer documents, payment cards and other means of access to bank accounts, electronic money, equipment for their production (Article 200 of the Criminal Code of Ukraine); legalization (laun-dering) of proceeds from crime (Art. 209 of the CC of Ukraine); bringing the bank to insolvency (Art. 2181 of the Criminal Code of Ukraine); making the bank bankrupt (Art. 219 of the Criminal Code of Ukraine); violation of the rules of conducting a database of depositors or the rules of reporting (Art. 2201 of the Criminal Code of Ukraine); falsification of financial documents and financial institution reporting, concealment of a financial institution insolvency or grounds for revoking (cancelling) a license of a financial institution (Art. 2202 of the Criminal Code of Ukraine); fraud with financial resources (Art. 222 of the Criminal Code of Ukraine); illegal collection for the purpose of using or making use of information constituting commercial or banking secrets (Art. 231 of the Criminal Code of Ukraine); and disclosure of commercial or banking secrets (Art. 232 of the Criminal Code of Ukraine). All these crimes are intentional and unlawfully motivated.

IT supports nearly all processes or makes such processes possible in the first place (Kokert \& Held, 2013). Direct banks are subject to the same laws and regulations as traditional banks. Sophisticated encryption software is designed to protect your account information, but no system is perfect. Accounts may be subject to phishing, hacker attacks, malware and other unauthorized activity (Michael, 2018). The importance of information and communications technology (IT) for credit institutions has grown substantially over the past two decades.

Taking into account the active course of Ukraine for European integration and related economic reforms, we can confidently state that the dynamic development of social relations in Ukraine outstrips the development of its legislation. The complication of social relations in the process of their development in Ukraine, inconsistent administrative decisions, which lead to more negative than positive changes, ignoring positive foreign experience in the field of ensuring the banking sector security in Ukraine, and simultaneously "superficial" perception by the legislator of the course of humanizing criminal legislation without taking into account the peculiarities of functioning the country's economic system and its key components during the period of instability and military conflicts lead to an increase in the public relations criminalization in Ukrainian banking.

Thus, public relations, not sufficiently regulated at the legislative level, are not good for strengthening the 
national economy; what is more, they complicate its development and make the support through foreign investments impossible. This is due to the fact that the current legislation of Ukraine is not capable of providing adequate banking security with its norms, including criminal law ones. In particular, the analysed statistical indicators of recent years show a significant level of banking criminalization in Ukraine. Note that due to the lack of their unified accounting and systematization, these data cannot be considered absolutely accurate, although they are as close as possible to the actual state of criminal offenses committed in the investigated sphere, as they are determined based on the information reflected in the annual reports of the Deposit Guarantee Fund (hereinafter - DGF) and the annual reporting statistics of the Prosecutor General's Office of Ukraine on the crime rate.

It should be noted that the issue of latent crime in the banking sector, which is believed to be the usual documentary or financial mistakes, is being unduly neglected by analysts of law-enforcement bodies and criminologists.

The DGF was formed in accordance with the Decree of the President of Ukraine: "On Measures to Protect the Rights of Individuals - Contributors of Commercial Banks of Ukraine" No. 996/98 dated September 10, 1998. However, the available DGF data on the number of offenses committed are from 2010 in the open press. Note that these data are not sufficiently specified, therefore, we consider them to be somewhat superficial.

In particular, according to the DGF, information on criminal offenses committed in the field of banking is available from 2014. And from 2010 to 2013, reporting data on audits carried out by the DGF as a controlling body is presented in the framework of ensuring the functioning of the deposit guarantee system, protecting the rights and interests of depositors who are participants or temporary participants of the DGF. That is, the open press gave no completely accurate information on the crimes committed in this period in DGF banking activity. Thus, according to the DGF report, in 2010, 101 violations were detected among 50 DGF participants (temporary participants).

In total, in 2011, 97 violations were detected among 58 participants. The total number of banks in which database management deficiencies were found out based on the Instruction on the creation procedure of individual depositors' database from the DGF participants, approved by the DGF Administrative Council decision as from November 14, 2002 No. 13, was 46 banks, which is $22.44 \%$ of the total number of established violations by banks in 2012. In 2013, 524 violations were detected among 87 DGF participants.

Available data is on criminal offenses in banking for the period of 2013-2016 according to the DGF annual reports. In 2014, the DGF began active work to bring to justice the perpetrators of offenses in insolvent banks. The DGF developed Guidelines for the DGF authorized persons to initiate criminal prosecution of perpetrators. As of December 31, 2015, 2494 applications on criminal offenses were filed by the DGF authorized persons to the Ministry of Internal Affairs, the Prosecutor's Office, the Security Service of Ukraine, and the State Fiscal Service (hereinafter - the SFS). In the same year, upon 10 applications, the suspected persons were notified on suspected malfeasance (crimes amounting to 26,090 bln UAH); 105 applications closed the proceedings; materials for 6 applications were sent to the court; in one case, the court issued a verdict of not guilty (the case concerns the funds of PJSC "Tavrika Bank" in Meinlbank) (Richnyi zvit, 2016).

According to the 2016 results of the DGF Department of Investigation of Offenses and the DGF authorized persons, 1113 references on criminal offenses were sent to law enforcement agencies, according to the results of which, 492 criminal proceedings were instituted, 9 of which were indictments to the court.

Also, in 2016, within the investigating criminal proceedings, in order to provide compensation for damage caused by criminal offenses, the DGF filed 103 civil lawsuits. Improving criminal records of crimes committed in the banking sector and analysing the consequences of these criminal offenses will allow to conduct a deep analysis and to focus the efforts of both theorists and practitioners on identifying and eliminating the causes and conditions that create a favourable environment for committing these abuses. It is difficult to understand at the present time which criteria are used to compile the DGF reports and those of the Prosecutor General's Office of Ukraine regarding the abuses committed in the area investigated. The ambiguity of terminological definitions in these reports also does not allow for objective information about their objective indicators. So, among the terms, DGF experts apply when presenting statistical data on offenses in the banking business, the following are used: bank breach, the violation in insolvent banks, and criminal offenses.

\section{Conclusion}

The necessity of criminal law protection of banking activities is due to the increased public danger of these acts at the present stage of the society's functioning, the crisis in the financial and banking spheres, the urgent needs to eliminate the gaps in the current legislation of Ukraine on security issues in the banking sphere. In addition, directly within the banking sector, the introduction of a regulatory framework for warning against possible crimes, the attraction of qualified and highly moral personnel, the introduction of effective systems for the banking information protection, etc., should be priority areas of management. The provisions of the Basel Committee on Banking Supervision reflect the high and uniform 
standards in banking regulation and supervision. Dealing with long-term systemic security problems in banking is a crucial task in the area of adaptation of the Ukrainian banking legislation to the EU requirements.

Adaptation of Ukraine's legal standards to the EU Directives' requirements should be made by amending certain legislative acts of Ukraine in order to increase the trust between banks and their clients; criminalization of actions in banking that contain a sign of social danger; liberalization of currency transactions to promote investments and exports; improvement in protecting the rights of financial service consumers; ensuring the NBU activities transparency and increasing its liability to society, improving the deposit guarantee system. It is necessary to form the proper jurisprudence for dealing with offenses in banking in order to properly assess them and bring the perpetrators to justice. At the same time, it is necessary to introduce a unified terminology that would indicate offenses (administrative and criminal) in the banking sector. At the present time, the procedure for preparing statistical reports (accounting) for criminal offenses is regulated by departmental orders.

Therefore, at least, it is necessary to have a general unified procedure for such reporting or adoption of a separate Law of Ukraine "On Criminal Records". Such legislative changes would have an effective impact on reducing the level of the banking sector criminalization in Ukraine, which would have a positive effect on accelerating adaptation processes of domestic legislation to international standards. Under unfavourable market conditions and outflow of capital, the problems of the banking sphere criminalization in Ukraine cause crisis phenomena, which complicate the adaptation of the domestic legislation to the EU Directives' requirements.

The actual state of things in the area of adaptation of Ukrainian legislation on banking security to European standardscannotbedefinedas satisfactory. Ukraineneeds a thorough analysis of comments, recommendations, and proposals of European institutions on these issues. We believe that strengthening efforts and their effectiveness in this direction are also possible in the context of systematic public reporting of responsible authorities on taking these adaptation measures.

Lack of response of regulatory authorities to adverse conditions arising in the process of functioning of public relations in banking without the use of a specific strategy leads to socially dangerous consequences. However, the state has determined public and legal regulation and protection of social relations as its priority in banking. Therefore, it is necessary to create an appropriate adaptation strategy that would take into account and deal with a holistic range of problematic issues that complicate and slow down the NBU's tasks with regard to the integration processes of banking legislation.

\section{References:}

Baranovskyi, O. (2014). Bezpeka bankivskoi sfery [Security of banking sector]. Visnyk Natsionalnoho Banku Ukrainy, 6, 20-27.

Dudorov, O. O., Movchan, R. O. (2015). Kryminaljno-pravova zaborona shchodo dovedennia banku do nesplatospromozhnosti: sumnivna zakonodavcha novella [Criminal prohibition on bringing the bank to insolvency: questionable legislative short story]. Pravo i ghromadjansjke suspiljstvo, 1, 71-115.

Jayaprakash, Nair (2016). Analytics Applied - Fraud prevention and detection in the Banking sector. Retrieved from: http://blog.aspiresys.com/digital/big-data-analytics/analyticsapplied-fraud-prevention-anddetection-inthe-banking-sector

Kanungo, R., Al-Shawabkeh, A. (2017). Credit risk estimate using internal explicit knowledge. Investment Management and Financial Innovations, 14(1), 55-66. Retrieved from: http://dx.doi.org/10.21511/imfi.14(1).2017.06

Klochko, A. M., Nezhevelo, V. V. (2017). Determinanty zlochynnosti u sferi bankivskoi diialnosti Ukrainy [Determinants of crime in banking activity in Ukraine]. Retrieved from: http://lsej.org.ua/6_2017/88.pdf

Klochko, A. N., Kurilo, N. P., Zapara, S. I. (2017). K voprosu ugolovno-pravovoy okhrany sfery bankovskoy deyatelnosti Ukrainy [On issue of penal and legal protection in baking sphere of Ukraine]. Vserossiyskiy kriminologicheskiy zhurnal, 11(4), 833-843. Retrieved from: http://dx.doi.org/10.17150/25004255.2017.11(4).837

Kokert, J., Held, M. (2013). IT Security: Expectations of banking supervision. Retrieved from: https://www.bafin.de/ SharedDocs/Veroeffentlichungen/EN/Fachartikel/2013/fa_bj_2013_11_it_si-cherheit_en.html

Konig, E. (2017). Implementing an efficient resolution framework in the Banking Union: lessons from the crisis and challenges ahead, 71-76. Retrieved from: https://publications.banque-france.fr/sites/default/files/medias/ documents/fsr21_web.pdf

Kurilo, M., Klochko, A., Timchenko, G., Gulyk, A. (2017). Banking in Ukraine as an object of criminal and legal protection. Banks and Bank Systems, 12(4), 114-120. Retrieved from: http://dx.doi.org/10.21511/ bbs.12(4).2017.11

Kurylo M., Klochko A., Zhuravlov D., Javadov H. (2018). Economic and legal aspects of banking security under European integration intensification in Ukraine. Banks and Bank Systems, 13(1), 162-172. http://dx.doi.org/10.21511/bbs.13(1).2018.15

Michael, G. (2018). The Pros and Cons of Internet Banks. Retrieved from: https://www.investopedia.com/ articles/pf/11/benefits-and-drawbacks-of-internet-banks.asp 
Migiro, S. (2017). Post National Credit Act reckless lending in the South African banking industry. Public and Municipal Finance, 6(2), 27-34. Retrieved from: http://dx.doi.org/10.21511/pmf.06(2).2017.03

Palmer, K. (2011). Is It Safe to Bank Online? Ten ways to keep your information secure in the wake of high-profile cyberattacks. Retrieved from: https://money.usnews.com/money/personal-finance/articles/2011/06/13/is-itsafe-to-bank-online

Prokopenko, N. S., Vykliuk M. I. (2014). Skladovi bezpeky bankivskoi diialnosti [Security components of banking activities]. Naukovyi Visnyk NLTU Ukrainy, 24.1, 302-308.

Shcherbatykh, D. V., Shpyliovyi, B. V. (2016). Pidkhody ta zahrozy do formuvannia finansovo-ekonomichnoi bezpeky bankivskykh ustanov [Approaches and risks to formation of finance and economic security of banking establishments]. Visnyk Cherkaskoho Universytetu. Seriia Ekon. Nauky, 1, 141-148.

Swanepoel, E., Smit, A. M. (2016). The impact of executive remuneration on risk-taking in the banking industry. Investment Management and Financial Innovations, 13(3), 110-117. Retrieved from: http://dx.doi.org/10.21511/ imfi.13(3).2016.10

Ter-Akopov, A. A. (2003). Prestupleniye i problemy nefizicheskoy prichinnosti v ugolovnom prave [Crime and problems of non-physical causation in criminal law]. Moscow: Yurkniga. (in Russian)

Vasylchak, S. V., Motsio, R. Yu. (2009). Ekonomichna bezpeka bankiv ta metody yii zabezpechennia [Economic security of banks and methods for its ensuring]. Naukovyi Visnyk NLTU Ukrainy, 19.12, 287-292.

Vovchenko, R. C. (2015). Pidkhody do rozkryttia sutnosti finansovoi bezpeky bankivskoho sektoru natsionalnoi ekonomiky [Approaches to essence reveal of finance security of banking sector of national economy]. Zbirnyk naukovykh prats "Finansovo-kredytna diialnist: problemy teorii ta praktyky", 19, 1-59. Retrieved from: http://fkd.org.ua/ article/view/56896/53702

Weigand, R. A. (2016). The performance and risk of banks in the U.S., Europe and Japan post-financial crisis. Investment Management and Financial Innovations, 13(4), 75-93. Retrieved from: http://dx.doi.org/10.21511/ imfi.13(4).2016.07

Kryminalnyi kodeks Ukrainy [The Criminal code of Ukraine]. Retrieved from: http://zakon3.rada.gov.ua/laws/ show/2341-14

Pro banky i bankivsku diyalnist ["About banks and banking” Law of Ukraine dated December 7, 2000 № 2121-II] Retrieved from: http://zakon2.rada.gov.ua/laws/show/2121-14

Pro zakhody shchodo zakhystu prav fizychnykh osib - vkladnykiv komertsiinykh bankiv Ukrainy. Ukaz Prezydenta Ukrainy vid No. 996/98 ["On Measures to Protect the Rights of Physical Persons as Depositors of Commercial Banks of Ukraine": the Decree of the President of Ukraine dated 10.09. 1998 No. 996/98]. Retrieved from: http://zakon5.rada.gov.ua/laws/show/996/98

Richnyi zvit 2016. Fond harantuvannia vkladiv fizychnykh osib [Annual Report 2016. Deposit Guarantee Fund]. Retrieved from: http://www.fg.gov.ua/images/docs/reports/Annual_report_FGVFO_zvit_2016_ukr.pdf

Richnyi zvit Fondu harantuvannia vkladiv fizychnykh osib za 2015 rik [Annual Report of Deposit Guarantee Fund for 2015]. Retrieved from: http://www.fg.gov.ua/images/docs/reports/Звіт_Фонду_гарантування_3а_2015.pdf

Fond harantuvannia vkladiv fizychnykh osib. Zvit za 2011 rik [Deposit Guarantee Fund. Report for 2011]. Retrieved from: http://www.fg.gov.ua/files/docs/reports/Zvi-t2011ukr.pdf

Fond harantuvannia vkladiv fizychnykh osib. Zvit za 2012 rik [Deposit Guarantee Fund. Report for 2012]. Retrieved from: http://www.fg.gov.ua/files/docs/reports/Zvit_FGVFO_ukr_2012.pdf

Fond harantuvannia vkladiv fizychnykh osib. Richnyi zvit 2013 [Deposit Guarantee Fund. Report for 2013]. Retrieved from: http://www.fg.gov.ua/files/docs/reports/Zvit_FGVFO_ukr_2013.pdf

Fond harantuvannia vkladiv fizychnykh osib. Richnyi zvit 2014 [Deposit Guarantee Fund. Report for 2014]. Retrieved from: http://www.fg.gov.ua/images/docs/reports/zvit_2014_ukr.pdf

Fond harantuvannia vkladiv fizychnykh osib. Richnyi zvit 2015 [Deposit Guarantee Fund. Report for 2015]. Retrieved from: http://www.fg.gov.ua/images/docs/reports/zvit_2015_ukr.pdf

Fond harantuvannia vkladiv fizychnykh osib. Richny zvit za 2016 rik [Deposit Guarantee Fund. Report for 2016]. Retrieved from: http://www.fg.gov.ua/images/docs/reports/Annual_report_FGVFO_zvit_2016_ukr.pdf

Fond harantuvannia vkladiv fizychnykh osib. Richny zvit za 2017 rik [Deposit Guarantee Fund. Report for 2017]. Retrieved from http://www.fg.gov.ua/images/docs/reports/Annual_report_FGVFO_zvit_2017_ukr.pdf 